Aquaculture Research

September 2017, Volume 48, Issue 9, Pages 4756-4773

http://dx.doi.org/10.1111/are.13297

http://archimer.ifremer.fr/doc/00377/48817/

(C) 2017 John Wiley \& Sons Ltd

\title{
Influence of feeding regime and temperature on development and settlement of oyster Ostrea edulis (Linnaeus, 1758) larvae
}

\author{
Robert René ${ }^{1,{ }^{*}}$, Vignier Julien ${ }^{2}$, Petton Bruno ${ }^{3}$ \\ ${ }^{1}$ Ifremer, Unité Littoral; Centre Bretagne - ZI de la Pointe du Diable; Plouzané, France \\ ${ }^{2}$ Plateforme Stella Mare (UMS CNRS 3514); Biguglia ,France \\ ${ }^{3}$ Ifremer; Laboratoire de Physiologie des Invertébrés Marins (UMR 6539, LEMAR); Plouzané ,France \\ * Corresponding author : René Robert, email address : rene.robert@ifremer.fr
}

\begin{abstract}
:
Under controlled conditions of food density and temperature, larval performances (ingestion, growth, survival and settlement success) of the flat oyster, Ostrea edulis, were investigated using a flow-through rearing system. In the first experiment, oyster larvae were reared at five different phytoplankton densities $\left(70,500,1500,2500\right.$ and $3500 \mu \mathrm{m}^{3} \mu \mathrm{L}^{-1}: \approx 1,8,25,42$ and 58 cells $\mu^{-1}$ equivalent TCg), and in the second, larvae were grown at four different temperatures $\left(15,20,25\right.$ and $30^{\circ} \mathrm{C}$ ). Overall, larvae survived a wide range of food density and temperature, with high survival recorded at the end of the experiments. Microalgae concentration and temperature both impacted significantly larval development and settlement success. A mixed diet of Chaetoceros neogracile and Tisochrysis lutea (1:1 cell volume) maintained throughout the whole larval life at a concentration of $1500 \mu \mathrm{m}^{3} \mathrm{\mu L}^{-1}$ allowed the best larval development of $O$. edulis at $25^{\circ} \mathrm{C}$ with high survival $(98 \%)$, good growth $\left(16 \mu \mathrm{m} \mathrm{day}{ }^{-1}\right)$ and high settlement success $(68 \%)$. In addition, optimum larval development (survival $\geq 97 \%$; growth $\geq 17 \mu \mathrm{m}$ day $\left.^{-1}\right)$ and settlement $(\geq 78 \%)$ were achieved at 25 and $30^{\circ} \mathrm{C}$, at microalgae concentrations of $1500 \mu \mathrm{m}^{3} \mathrm{\mu L}^{-1}$. In contrast, temperature of $20^{\circ} \mathrm{C}$ led to lower development $\left(\leq 10 \mu \mathrm{m}\right.$ day $\left.^{-1}\right)$ and weaker settlement $(\leq 27 \%)$, whereas at $15^{\circ} \mathrm{C}$, no settlement occurred. The design experiments allowed the estimation of the maximum surface-area-specific ingestion rate $\left\{\dot{J}_{\mathrm{Xm}}\right\}=120 \pm 4 \mu \mathrm{m}^{3} \mathrm{day}^{-1} \mu \mathrm{m}^{-2}$, the half saturation coefficient $\left\{X_{K}\right\}=537 \pm 142 \mu \mathrm{m}^{3} \mu \mathrm{L}^{-1}$ and the Arrhenius temperature $T_{\mathrm{A}}=8355 \mathrm{~K}$. This contribution put a tangible basis for a future O. edulis Dynamic Energy Budget (DEB) larval growth model.
\end{abstract}




\section{Introduction}

The European flat or "Native" oyster, Ostrea edulis, propagates along European shores, from the coasts of Norway to Morocco, including the Mediterranean Sea (Harry, 1985; Shpigel, 1989). At the end of the 1970s, two successive outbreaks associated with the parasites Marteilia refringens and Bonamia ostreae dramatically impacted $O$. edulis populations. French production (mainly located in Brittany) dropped from $24000 \mathrm{t}$ in the late 1960 s to present levels of 1000-1500 t (Buestel et al., 2009; Robert et al., 2013). The extension of such disease across Europe led to the collapse of this industry at the European level (Baud et al., 1997 and references therein; da Silva et al., 2005 and references therein) with most of the works since devoted to a better knowledge of both illness in natural surroundings (e.g. : Berthe et al., 2004; Culloty and Mulcahy 1996; Flanery et al, 2014; Montes et al., 1991; van Banning 1991) or under controlled conditions (Arzul et al., 2009; da Silva et Villalba, 2004; Lallias et al., 2008, Prado-Alvarez et al., 2015). Different strategies have been tried to minimize the effect of these diseases, such as modified husbandry (e.g. Le Bec et al., 1991; Robert et al., 1991), introduction of exotic flat oysters (e.g. Ostrea puelchana: Pascual et al., 1991), genetic improvement (Montes et al., 2003; Naciri-Graven et al., 1998) or oyster bed restoration (Laing et al., 2005; Lallias et al., 2010; Sawusdee et al., 2015). The situation was similar for most countries in Europe after the disease spread and flat oyster populations have never recovered. In this context, except for some limited disease-free areas (e.g. Scotland, North of Ireland, Norway, Sweden, Denmark and Croatia), flat oyster farming consists of improving oyster growth before the fateful limit of 3 years old or equivalent size and, accordingly, $O$. edulis production in Europe is constrained. Currently, a selective breeding program provides a possibility to enhance flat oyster farming as demonstrated earlier for Crassostrea virginica (Ford et al., 1990) or C. gigas (Ward et al., 2000) and progress has been made in breeding for diseases resistance (Lynch et al., 2014) including the use of new genetic tools for improving selection (Harrang et al., 2015; Lallias et al., 2009; Martin-Gomez et al., 2012; Morga et al., 2010, 2012). Such targeted genetic improvement, however, will not be feasible until the lack of reliable methods in hatchery production for this species is overcome. In France, the decrease of $O$. edulis production led to the introduction in 1971 of the Pacific oyster, Crassostrea gigas which successfully became the major species farmed in France comprising $98 \%$ of oyster production (Grizel and Héral, 1991; Robert et al., 2013). Since 
2008 however, massive losses in the French shellfish industry due to summer mortalities of $C$. gigas associated to the OsHV-1 (e.g.: Pernet et al., 2012; Renault, 2011) contributed to the reconsideration of $O$. edulis as an alternative production in a context of diversification. Both conditions were filled to give back interest to $O$. edulis production under controlled conditions.

Hatchery techniques are now relatively well-known for many bivalve species such as $C$. gigas (Utting and Spencer, 1991), Ruditapes philippinarum (Helm and Pellizzato, 1990) or Mercenaria mercenaria (Castagna and Kraeuter, 1981). Although great knowledge has been acquired by pioneer works such as Walne $(1965,1966,1979)$, the state of the art in hatchery culture of $O$. edulis has remained insufficient to support a reliable seed production, probably due to a lack of updated and detailed knowledge of the biology of this species. The life cycle of marine bivalves is strongly related to environmental parameters such as temperature and food availability as well as to cycles of storage and utilization of biochemical substrates (Burke et al., 2008; Fabioux et al., 2005; Rico-Villa et al., 2010). Through a European project called "SETTLE" we addressed efforts to fill this gap. Firstly, we focused on broodstock conditioning by studying the effects of food on $O$. edulis reproduction, because it is the first step to master in hatchery to allow production of larvae of good initial quality. This point is particularly crucial for $O$. edulis that is a larviparous species with high maternal effects that have been shown to affect larval growth and survival (Berntsson et al., 1997). Based on ingestion and assimilation of different microalgae species combined to fatty acid and sterol transfer from diet to gonad, we selected an appropriate diet for $O$. edulis broodstock conditioning based on a mixed diet of Rhodomonas salina and Chaetoceros neogracile (Gonzalez-Araya et al., 2011, 2012a, 2013). Thereafter, we focused on the effects of food assemblage (quality aspects) on O. edulis larval development that confirmed the efficiency of a bispecific diet $v s$ single diet for larvae regardless to broodstock diet (Gonzalez-Araya et al., 2012 b).

The present work, which is in the continuity of the "SETTLE" project, will be addressed to the effects of temperature and food (quantity aspect) on $O$. edulis larval development. Such work relies on recent advances in the development of continuous flow-through systems for larvae that have shown to be efficient for Pecten maximus (Magnesen et al., 2006) or C. gigas (Rico-Villa et al., 2008). These improvements in rearing methods using flow-through systems can be applied to $O$. edulis culture, thus reducing the constraints involved in the generally used "static system", such as tank cleaning, frequent water renewal or stress related to larval handling (Rico-Villa et al., 2008). Indeed, unexplained flat oyster larval mortalities have often 
been reported in hatchery on day 8 and at post-settlement (anonymous, 2004; Laing et al., 2005). Moreover, these optimized flow-through units consisting of relatively small volume containers (5 1), stocked at high larval densities and supplied by a constant flow of phytoplankton-enriched seawater, can allow greater replication and a better control of larval rearing parameters. Flow-through systems may help to overcome larval mortalities of $O$. edulis in hatchery, which have been often associated with bacterial contamination such as Vibrio (Jeffries, 1983; Prado et al., 2005; Elston et al., 2008).

The aim of the present study was to determine the optimal temperature and phytoplankton concentration for the hatchery culture of Ostrea edulis larvae, based on survival, larval growth, ingestion and metamorphosis.

\section{Material and methods}

\subsection{Broodstock conditioning}

A total of 250 four-year-old, Bonamia and Marteilia-free, flat oysters (O. edulis) originating from Norway, were maintained under controlled conditions, at the Ifremer Argenton hatchery from the end of the hatchery spawning period. From mid-July to December, oyster broodstock were progressively decreased from $19^{\circ} \mathrm{C}$ to $10^{\circ} \mathrm{C}\left(1^{\circ} \mathrm{C}\right.$ per week) and held in shadow light, in three 700-1 flow-through tanks supplied with 10- $\mu$ m filtered, UV-sterilized seawater. Oysters were continuously fed Tisochrysis lutea (CCAP 927/14: T) plus Chaetoceros neogracile (UTEX LB2658: Cg) by means of a peristaltic pump. From mid-December onward, they were progressively acclimated to $19^{\circ} \mathrm{C}\left(1^{\circ} \mathrm{C}\right.$ per week increase), with permanent light, in $1 \mu \mathrm{m}$ cotton bag filtered seawater, UV treated, and continuously enriched with Rhodomonas salina (CCAP 978/24) plus C. neogracile. When temperature reached $19^{\circ} \mathrm{C}$ broodstock received a daily ration of $6 \%$ dry weight microalgae $(\mathrm{mg})$ per oyster meat $(\mathrm{g})$. Tanks were drained and daily cleaned, and treated once a week with a bactericide/fungicide/virucide solution by pulverization.

\subsection{Larval rearing}

Following 6 weeks of conditioning and onwards, expelled larvae were collected from the water surface by means of sieves placed under the outflow. At each release, larvae were counted and the number of Vibrio sp. per larvae was determined. The batch of larvae was kept when Vibrio load was $<1$. In this condition and when a sufficient number of larvae were 
obtained to allow the set-up of 15 experimental conditions, larvae were distributed in 5-1 translucent methacrylate cylinders in triplicate per experimental condition, and reared in flowthrough with $1-\mu \mathrm{m}$ cartridge filtered and UV-treated seawater (FSW). After degasification in a column to avoid bubble disease, FSW was maintained at different experimental temperature (see 2.3) and ambient salinity (34 PSU), at a renewal rate of $100 \% \mathrm{~h}^{-1}$, i.e. $87 \mathrm{ml} \mathrm{min}^{-1}$. Oyster larvae were fed a bispecific algal diet consisting of Tisochrysis lutea $\left(\approx 40 \mu \mathrm{m}^{3}\right.$ volume diameter) and Chaetoceros neogracile $\left(\approx 80 \mu \mathrm{m}^{3}\right)$ continuously maintained by peristaltic pumps at different experimental concentration (see 2.4). Food remained suspended in the water column by means of air, bubbling from the base of the cone $\left(30 \mathrm{ml} \mathrm{min}^{-1}\right)$. Air was previously filtered at $0.2 \mu \mathrm{m}$.

\subsection{Temperature experiment}

\subsubsection{System design}

Following release from the broodstock, larvae were distributed in triplicate in 5-1 translucent methacrylate cylinders at four different temperatures: $15,20,25$ and $30^{\circ} \mathrm{C}$. Larvae were held at a density of 50 larvae $\mathrm{ml}^{-1}$ in FSW and fed a bispecific diet (T. lutea plus C. neogracile) continuously maintained at $1500 \mu \mathrm{m}^{3} \mu \mathrm{l}^{-1}$, previously determined as the best phytoplankton concentration for Crassostrea gigas (Rico-Villa et al., 2009) and confirmed here for O. edulis larval development (see 2.4). To allow for the maintenance of four temperatures without any disturbance, two larval rooms were used (Fig 1). Seawater at the entry of the first room was continuously maintained at $15^{\circ} \mathrm{C}$ by means of a thermo-regulated flow gate; whereas, the FSW at the entry of the second room was continuously thermo-regulated at $30^{\circ} \mathrm{C}$. Both thermo-regulated filtered-seawater (FSW) flows were either delivered directly to the rearing cylinders (via 2 columns of degasification) or mixed in 2 tanks to allow the acquisition of the 2 other temperatures, 20 and $25^{\circ} \mathrm{C}$. Seawater was distributed from these tanks to the cylinders by means of pumps.

\subsubsection{Sampling procedure}

Few larvae were lost during larval rearing and accordingly, larval performances reported here relate to the whole population. According to Rico-Villa et al (2009), larval growth and metamorphosis of $C$. gigas are closely associated to temperature. For this reason, we used the daily cumulated temperature (degree-days or ${ }^{\circ}$ days) to allow comparison of different conditions in a similar scale, by adding all temperatures every day. To assess larval growth, 15 to $20 \mathrm{ml}$ of FSW containing larvae $(\mathrm{n} \geq 175)$ were sampled from each cylinder. Larval size 
was estimated every second day under the microscope using image analysis techniques (WinImager 2.0 and Imaq Vision Builder 6.0 software for image capture and treatment respectively). Larval survival was estimated at the end of the larval period at $\approx 180^{\circ}$ days (days 6 to 13 at temperature ranging from $15^{\circ} \mathrm{C}$ to $30^{\circ} \mathrm{C}$ ) by direct counting of empty shells (dead larvae). Survival was also estimated at mid-metamorphosis $\approx 270^{\circ}$ days (days 9 to 16 ) and at the end of the metamorphosis $\approx 270^{\circ}$ days (days 12 to 18 ). Rearing cylinders were drained and the whole larval population was transferred in 100-ml test tubes to be precisely sampled $(6 \times 200 \mu 1$ to $6 \times 500 \mu 1)$. The percentage of eyed larvae (i.e. competent) was recorded at $\approx 180^{\circ}$ days before transferring the whole population to similar larval cylinders without any cultch nor epinephrine for another week of rearing to allow metamorphosis. Settlement success (in \%) was indirectly estimated 3 and 6 days later (days 9 to 18 from release) by determining the number of remaining larvae (absence of dissoconch). Complementary trials were run at 20 and $25^{\circ} \mathrm{C}$ to verify the effects on survival, growth and metamorphosis. Seawater temperature was daily controlled at the inlet of each larval rearing.

\subsubsection{Ingestion rates}

Enriched FSW was sampled twice a day at the inlet and outlet of each larval rearing cylinder to control larval ingestion by means of a particle coulter counter (Multisizer 3) and to adjust the food input in case of deviation from the theoretical value. In a flow-through culture system, larval ingestion rate (IR) expressed in $\mu \mathrm{m}^{3} \mathrm{~d}^{-1}$ larvae ${ }^{-1}$ corresponds to:

$$
\mathrm{IR}=\left(\left(\mathrm{C}_{\mathrm{i}}-\mathrm{C}_{\mathrm{o}}\right) * \mathrm{~S}_{\mathrm{F}}\right) / \mathrm{N}
$$

where $C_{i}=$ food concentration of the incoming seawater and $C_{o}=$ food concentration of the outcoming seawater $\left(\mu \mathrm{m}^{3} \mu \mathrm{l}^{-1}\right) ; \mathrm{S}_{\mathrm{F}}=$ seawater flow $\left(\mu \mathrm{d} \mathrm{d}^{-1}\right)$, recorded twice a day; and $\mathrm{N}=$ number of larvae in each tank.

\subsection{Feeding ratio experiment}

\subsubsection{System design}

Following release, larvae were counted and distributed in triplicate in 5-1 translucent methacrylate cylinders. Larvae were held at a density of 50 larvae $\mathrm{ml}^{-1}$ in FSW and fed continuously, by means of four peristaltic pumps, a bispecific diet (1:1) consisting of T. lutea plus $C$. neogracile at different phytoplankton concentrations: $70 \mu \mathrm{m}^{3} \mu \mathrm{l}^{-1}$ (no microalgae added); $500 \mu \mathrm{m}^{3} \mu \mathrm{l}^{-1} ; 1500 \mu \mathrm{m}^{3} \mu \mathrm{l}^{-1} ; 2500 \mu \mathrm{m}^{3} \mu \mathrm{l}^{-1} ; 3500 \mu \mathrm{m}^{3} \mu \mathrm{l}^{-1}$. 


\subsubsection{Sampling procedure}

Larval growth was assessed every second day by sampling 15 to $20 \mathrm{ml}$ of FSW containing larvae $(n \geq 175)$ from each cylinder, and larval shell length was estimated under the microscope using image analysis techniques. Larval survival at the end of the larval period was estimated at $\approx 150^{\circ}$ days (or day 6 ), at mid-metamorphosis ( $250^{\circ}$ days or day 9 ) and at the end of the metamorphosis period $\left(325^{\circ}\right.$ days or day 12$)$. Cylinders were drained and the whole larval population was transferred in 100-ml test tubes to be precisely sampled (6 x $200 \mu 1$ to 6 x $500 \mu 1$ ). The percentage of eyed larvae (i.e. competent) was recorded on day 6 before transferring the whole population to similar larval cylinders without any cultch nor epinephrine for another week of rearing to allow metamorphosis and settlement. Settlement success (in \%), that took place on the wall of the rearing unit, was estimated 4 and 7 days later (days 10 to 13 from release) by determining the number of remaining larvae (absence of dissoconch). Larval ingestion was estimated daily by means of a particle coulter counter (Multisizer 3) and the food ratio adjusted.

\subsection{Statistical analysis}

Statistical analyses were performed using STATISTICA software (version 8.0). Depending on the studied factors (temperature, food ration), one way analyses of variance (ANOVA) were performed on survival rates and settlement success data. Before ANOVA analysis, all percentage data were arcsine-square root transformed to improve normality. When significant effects of factors were found $(\mathrm{p} \leq 0.05)$, a posteriori multiple comparison of the means was performed (Tukey's test). Normality (Shapiro-Wilk test) and homogeneity of variances (Levene's test) were checked. When normality requirement was not met, a non-parametric test (Kruskal-Wallis test) was used for multiple comparisons of mean ingestion rate and shell length. To compare means of larval shell length at release $\left(\mathrm{T}_{0}\right)$ between the two successive experiments, a student t-test for independent samples was used $(\mathrm{p}<0.05)$.

\section{Results}

\subsection{Effects of temperature on survival and settlement}

At the end of the larval rearing, which lasted from day 6 to day 13 after release, survival was high $(\geq 92 \%)$, whereas at $15^{\circ} \mathrm{C}$, larval survival was lower (79\%: Table 1). At mid 
metamorphosis (i.e. from days 9 to 16), larval survival ranged from 0 to $43 \%$, while all unsettled larvae were dead from day 13.

Larval competence was low at $15^{\circ} \mathrm{C}(11.7 \%)$, and increased with temperature to reach $96 \%$ at $30^{\circ} \mathrm{C}$ at the end of the larval rearing, (Table 1). No settlement occurred at $15^{\circ} \mathrm{C}$ and was low at $20^{\circ} \mathrm{C}(\approx 30 \%)$. Best performances were recorded above $25^{\circ} \mathrm{C}$ with metamorphosis ranging from $78 \%$ to $90 \%$

\subsection{Effects of temperature on larval ingestion}

Food ingestion relied on temperature, and could be generally divided in three phases. A first phase of increase in food consumption was observed with an intensity and/or duration which were closely related to temperature. At $30^{\circ} \mathrm{C}$, the maximum consumption was obtained on day 5 with 135000 cells ingested per larvae but did not exceed 25000 cells at $15^{\circ} \mathrm{C}$ on day 7 (Fig. 2). A sharp decrease was thereafter observed (from day 5 to day 7) corresponding to metamorphosis. When sufficient settlement had occurred, an active re-initiation of consumption could be observed from days 8 to 11 at temperatures above $25^{\circ} \mathrm{C}$.

\subsection{Effects of temperature on larval growth}

Growth clearly relied on phytoplankton consumption (Fig. 2) with lower growth observed at $15^{\circ} \mathrm{C}$ from day 2 and higher growth at $30^{\circ} \mathrm{C}$ (Fig. 3). Daily growth from the day of release to the beginning of metamorphosis ranged from $4.3 \mu \mathrm{m} \mathrm{d}^{-1}$ to $21 \mu \mathrm{m} \mathrm{d}^{-1}$, and the pelagic larval period lasted 6 to 13 days $\left(175^{\circ}\right.$ days to $195^{\circ}$ days $)$. It is important to note that the effects of temperature on larval growth occurred swiftly. Indeed four days after release, the difference in length recorded between the two extreme temperatures $\left(15\right.$ and $\left.30^{\circ} \mathrm{C}\right)$ was $60 \mu \mathrm{m}$ for larvae whose initial mean length was $183.1 \pm 9.5 \mu \mathrm{m}$ (Fig. 3).

\subsection{Complementary experiment}

In the second consecutive experiment, the initial quality of the larvae (initial size $164 \pm 0.5$ $\mu \mathrm{m})$ was poorer because at release, $25 \%$ of dead larvae were already recorded despite no Vibrio detected. Accordingly, at the end of larval rearing (estimated at $225^{\circ}$ days), survival ranged from 42 to $53 \%$ (Table 2).

At $25^{\circ} \mathrm{C}$ daily larval length increments were similar between both trials $\left(15.5 \mu \mathrm{m} \mathrm{d}^{-1}\right.$ vs 17.5 $\mu \mathrm{m} \mathrm{d}^{-1}$ in the first trial); whereas at $20^{\circ} \mathrm{C}$ similar growth $\left(9.1 \mu \mathrm{m} \mathrm{d}^{-1} v s 10 \mu \mathrm{m} \mathrm{d}^{-1}\right.$ in the first trial) and settlement (25\% vs 27\%) were recorded (Tables 1 and 2). 


\subsection{Effects of food density on survival and settlement}

Regardless of food concentration from 70 to $3500 \mu \mathrm{m}^{3}$, larval survival was high, i.e. $\geq 89 \%$, on day 6 at $25^{\circ} \mathrm{C}\left(150^{\circ}\right.$ days: Table 3$)$. During metamorphosis, larval survival on day 10 ranged from 44 to $70 \%$ at the lowest food concentration, and from 19 to $29 \%$ for food concentration $\geq 1500 \mu \mathrm{m}^{3}$. On day 13 , all larvae were dead regardless of food concentration.

On day 6, competence was nil at a phytoplankton concentration of $70 \mu \mathrm{m}^{3}$ and low at all other food concentrations, i.e. $<20 \%$ (Table 3). No settlement took place at $70 \mu \mathrm{m}^{3}$. It was low at $500 \mu \mathrm{m}^{3}$ but exhibited best performances at $1500 \mu \mathrm{m}^{3} \mu \mathrm{l}^{-1}$ with $\approx 70 \%$ (Table 3 ).

\subsection{Effects of food density on larval ingestion}

Ingestion was highly dependent on food concentration and could generally be described as a three phase process. A first phase of increased consumption was observed with an intensity and/or duration closely related to phytoplankton density. At $3500 \mu^{3}$, maximum consumption was thus obtained on day 5 with 61000 cells per larvae, whereas at $500 \mu \mathrm{m}^{3}$ the highest consumption was 26000 cells per larvae on day 4.

A decrease was thereafter observed corresponding to metamorphosis and when sufficient settlement was reached, an active re-initiation of consumption was observed for phytoplankton densities above $1500 \mu \mathrm{m}^{3}$ from days 9-10 (Fig. 4). At $500 \mu^{3}$ a gradual decrease was observed from day 7 , corresponding to the beginning of larval mortality, while dispersion was higher $(\mathrm{CV}=26 \%$; Table 3$)$.

\subsection{Effects of food density on larval growth}

Lower growth was recorded at $500 \mu \mathrm{m}^{3} \mu \mathrm{l}^{-1}$ from day 4, and higher growth was recorded at food concentration $\geq 1500 \mu \mathrm{m}^{3} \mu \mathrm{l}^{-1}$. There were no significant differences between the three upper values (Fig. 5). Growth ranged from $10 \mu \mathrm{m} \mathrm{d}^{-1}$ to $17 \mu \mathrm{m} \mathrm{d}^{-1}$ before larval growth decreased due to the initiation of metamorphosis (the largest larvae being settled whereas the smallest remaining in the water column, meaning that such apparent decrease was an artefact), and total larval life lasted 8 to 9 days.

It is noteworthy that, regardless of food density, growth was similar during the first three days after release. However, compared to unfed larvae that exhibited a weak length increment during the first two days, additional food played a major role on growth since release. 


\section{Discussion}

The present study aimed to define the optimal temperature and phytoplankton concentration for the hatchery culture of the larvae of Ostrea edulis, a species with a regained interest in the French oyster industry. Under controlled conditions using a novel rearing method, the flowthrough system, this study demonstrated that larval performances such as growth rate, survival or settlement rate were highly dependent of temperature condition and feeding regime.

First of all, our study showed the relatively high temperature tolerance of $O$. edulis larvae (20 $-30^{\circ} \mathrm{C}$ ) with the best performances obtained $\geq 25^{\circ} \mathrm{C}$. The highest temperatures tested, i.e. 25 and $30^{\circ} \mathrm{C}$, resulted in the best larval performances, with high survival $(\geq 97 \%)$, high growth rates $\left(\geq 15.5 \mu \mathrm{m} \mathrm{d}^{-1}\right)$ and high settlement success $(\geq 78 \%)$. This is in agreement with RicoVilla et al. (2009) who, using a flow-through system, found that optimum larval development and settlement of $C$ gigas occurred at $27^{\circ} \mathrm{C}$. Early works showed that $O$. edulis larvae could be reared at a wide variety of temperature (Walne, 1965, 1966; Davis and Calabrese, 1969). However, some results obtained in the current work are contradicting with these pioneering studies and clearly show the need to update and improve the knowledge in larval rearing of $O$. edulis. According to Walne (1965), best larval results were obtained at about $22^{\circ} \mathrm{C}$ whereas Davis and Calabrese (1969) demonstrated that the ideal temperature range for satisfactory survival (i.e. $\geq 70 \%$ ) of $O$. edulis larvae was 12.5 to $27.5^{\circ} \mathrm{C}$, with poor survival occurring at $30^{\circ} \mathrm{C}$. This variability in results highlights the importance of larval rearing techniques used between studies (i.e. static $v s$ flow-through systems).

More specifically, increased ingestion was recorded as temperature increased throughout larval development. This increase of ingestion activity with temperature may be related to an increase of the ciliary activity of the larvae, in order to regulate metabolism (Strathmann, 1978; Baldwin and Newell, 1991). Our study also confirmed that O. edulis larval growth increased markedly with increasing temperature as previously shown in the literature (Walne, 1965; Robert et al., 1988). Maximum growth rate of the larvae was observed at $30^{\circ} \mathrm{C}$ but was not significantly different from $25^{\circ} \mathrm{C}$. These results are similar to Rico-Villa et al. (2009) which demonstrated that optimal temperature range for $C$. gigas larvae was between 27 and $32^{\circ} \mathrm{C}$, with no significant differences. Moreover, low mortalities $(\leq 5 \%)$ were recorded at $30^{\circ} \mathrm{C}$ at the end of the larval stage, suggesting that $30^{\circ} \mathrm{C}$ is not the upper thermal limit for $O$. edulis larvae. However, additional experiments should be accordingly carried out to determine 
upper thermal limits above $30^{\circ} \mathrm{C}$ for $O$. edulis larvae. For instance, previous studies on the larvae of O. edulis (Davis and Calabrese, 1969), C. gigas (Helm and Millican, 1977) and C. virginica (Davis and Calabrese, 1964) reported high mortalities at temperature $\geq 30^{\circ} \mathrm{C}, 32^{\circ} \mathrm{C}$ and $35^{\circ} \mathrm{C}$ respectively.

A rearing temperature of $30^{\circ} \mathrm{C}$ proved to have beneficial effects on metamorphosis leading to the highest settlement success of larvae (about 92\%). This result is in agreement with RicoVilla et al. (2009) who showed a positive relationship between metamorphosis of $C$. gigas and increasing temperatures. The lowest temperature tested $\left(15^{\circ} \mathrm{C}\right)$ did not significantly impact survival, with rates remaining relatively high (79\%). However, as shown by Rico-Villa et al. (2009) with $C$. gigas, the lowest temperature negatively affected ingestion rates, therefore reducing larval growth. Such impairment of larval growth may lengthen the larval period and increase the potential risks of predation, disease or dispersion (Davis and Hidu, 1969). As reported by Bayne (1983), extended larval period and delays in metamorphosis were observed (18 days) following exposure to low temperature, which directly impaired settlement success as shown by our data $(0 \%)$. This result demonstrates that $15^{\circ} \mathrm{C}$ should be considered as an unsuitable temperature for commercial hatchery culture of $O$. edulis from an economic approach. On the contrary, growing larvae at 25 or $30^{\circ} \mathrm{C}$ significantly improved survival, shortened the larval rearing period (i.e. 8 days) and clearly improved settlement success $(\geq$ 78\%). Consequently, these rearing temperatures are recommended for Ostrea edulis hatchery production. Nevertheless, great care must be taken when rearing larvae at $30^{\circ} \mathrm{C}$, especially in terms of feeding requirements and limitation of bacterial proliferation (Prado et al., 2005). For that reason and from an economic standpoint, a temperature of $25^{\circ} \mathrm{C}$ is recommended for larval production of flat oysters in hatchery.

Lastly, results from the present study suggest an ability of $O$. edulis larvae to adjust physiological processes in response to environmental temperature changes. In addition, this broad tolerance range of temperature may explain the extensive distribution of $O$. edulis along the European coast, from the cold waters of Norway or Scotland to the warm waters of the Mediterranean lagoons (Harry, 1985; Hidu and Lavoie, 1991; Shpigel, 1989).

In the current work, food was provided in a reliable and continuous way thanks to an efficient flow-through rearing system. As a result, larvae exhibited an adequate and sustained response in ingestion activity within a wide range of algae concentration. This study showed that larval development and metamorphosis were closely associated with feeding regime, which 
remained within a broad range of microalgae supply throughout larval rearing, from 70 to $3500 \mu \mathrm{m}^{3} \mu \mathrm{l}^{-1}$.

Our results showed however that during the first 2 days, whilst shell length was increasing, larval ingestion was relatively low and independent from the phytoplankton concentrations. This result suggests that newly released $O$. edulis larvae rely not only on exogenous source of food but also on maternal reserves (Labarta et al., 1999). This is in agreement with GonzalezAraya et al. (2012) who showed that diet assemblage during broodstock conditioning was influencing greatly initial larval quality. This mixotrophic phase could therefore explain the low ingestion activity observed. Following day 2, with the exception of the $500 \mu \mathrm{m}^{3} \mu \mathrm{l}^{-1}$ concentration, ingestion was highly dependent on microalgae concentration, and could be described as a three phase process. When larvae were surrounded by algal densities from 1500 to $3500 \mu \mathrm{m}^{3} \mu \mathrm{l}^{-1}$, ingestion increased significantly by 2 to 3 fold from day 0 to day 5 (phase 1). Microalgae ingestion then decreased, corresponding to the initiation of metamorphosis around day 9-10 (phase 2), until a sudden increase when the metamorphosis was completed and the newly settled spat started to feed again (phase 3). During larval development, the amount of food consumed becomes an essential factor in successful settlement as larvae must accumulate sufficient reserves to meet the energy demands required during the metamorphosis (Holland and Spencer, 1973). For that reason, ingestion activity increases very rapidly during phase 1 . The progressive decrease in food consumption observed during phase 2 can be explained by behavioural and morphological changes undergone by the pediveliger larvae. Indeed, when reaching competency for metamorphosis, late pediveliger larvae enhance their crawling behaviour using their foot to find a suitable substrate to settle on, hence reducing their filtration activity (Cole, 1937). Movement and feeding are also inhibited because the velum is absorbed and replaced by the gills (Cole, 1938b). These drastic anatomic changes may explain the decrease in ingestion rates observed at the end of the larval life, and the increase of ingestion observed during the post-metamorphic/benthic stage (phase 3).

Our results showed that the ingestion activity of $O$. edulis increased in relation to food density up to a threshold level above which ingestion remains fairly constant. This relationship was described for C. virginica (Baldwin and Newell, 1995) or Mercenaria mercenaria (Gallager, 1988) as a hyperbolic function which increased to a plateau. In mollusc larvae, ingestion capability is directly linked to the velar ciliary tract (Strathmann, 1978). To avoid impairing the digestive system function at a high concentration of particles, mollusc larvae have the ability to regulate their ingestion rates (Crisp et al., 1985) by cessation of the beating of the ciliary band (Strathmann and Leise, 1979) or by controlling the rate of ingestion or rejection 
of particles at the mouth (Gallager, 1988). Such a process has been called the saturation level and differs between species (Baldwin and Newell, 1995). For instance, Crisp et al. (1985) demonstrated that $O$. edulis larvae could reach a saturation level of ingestion rate at concentrations of 200 to 250 cells $\mu 1^{-1}$ using Pavlova lutheri as food supply. Based on cell volumes of a bispecific diet of $C$. neogracile and T. lutea (at $1: 1$ ) equivalent to $\approx 60 \mu \mathrm{m}^{3}$ (Gonzalez-Araya et al., 2012) our data could be converted into cell equivalents, resulting in a saturation level of 50 to 70 cells $\mu 1^{-1} \mathrm{TCg}$ equivalent diameter. This concentration is much lower than that found by Crisp et al. (1985) but higher than those reported by Rico-Villa et al. (2009) for $C$. gigas and by Baldwin and Newell (1995) for $C$. virginica, reaching 20 cells $\mu \mathrm{l}^{-1}$ and $10-40$ cells $\mu 1^{-1}$ of $T$. lutea respectively.

In addition, our results showed that growth was directly correlated with the food available to the larvae. At phytoplankton densities higher than $1500 \mu \mathrm{m}^{3} \mu \mathrm{l}^{-1}$, larval growth was not significantly improved and a plateau was reached. On the other hand, metamorphosis success, which was attained after 13 days, was significantly higher at phytoplankton densities of 1500 $\mu \mathrm{m}^{3} \mu \mathrm{l}^{-1}$. These results suggest that larvae surrounded by $1500 \mu \mathrm{m}^{3} \mu \mathrm{l}^{-1}$ (equivalent to $\approx 25$ cells $\mu \mathrm{l}^{-1}$ of $\mathrm{TCg}$ equivalent diameter) of a bispecific diet of microalgae throughout larval rearing achieved the best performances in terms of growth and metamorphosis. Consequently, this background concentration should be maintained throughout larval rearing of $O$. edulis in commercial hatcheries. Lastly, it is noteworthy to mention that when no algae was provided, larval survival was relatively high after 6 days (89\%) but started to be significantly affected from day $10(44 \%)$ to day $13(0 \%)$. Moreover, no competence or metamorphosis was recorded in starved larvae. These results clearly suggest that during their pelagic life, the amount of food consumed by the larvae is essential as they must store sufficient reserves to meet the energy demands required during the metamorphosis (Holland and Spencer, 1973) and to ensure their capacity for survival (Haws et al., 1993).

\section{Conclusion}

Using a flow-through rearing system, the present study determined the optimal temperature and feeding regime for the hatchery culture of $O$. edulis. At $30^{\circ} \mathrm{C}$, a mixed diet of T. lutea + C. neogracile maintained throughout the whole larval life at the concentration of $1500 \mu \mathrm{m}^{3} \mu^{-}$ ${ }^{1}$ allowed the best larval development of $O$. edulis with high survival (97\%), high growth $\left(21 \mu \mathrm{m} \mathrm{d}^{-1}\right)$ and high settlement $(92 \%)$. At $25^{\circ} \mathrm{C}$ larval performances were quite similar and accordingly this temperature is recommended for $O$. edulis larval rearing. In contrast 
temperature $\leq 20^{\circ} \mathrm{C}$ led to low development and weak settlement $(\leq 27 \%)$. At the temperature of $25^{\circ} \mathrm{C}$, a bispecific algal diet of $C$. neogracile $+T$. lutea maintained throughout the whole larval life at a concentration of $1500 \mu \mathrm{m}^{3} \mu \mathrm{l}^{-1}$ allowed the best larval development of $O$. edulis with high survival (99\%), good growth $\left(15 \mu \mathrm{m} \mathrm{d}^{-1}\right)$ and high settlement success $(68 \%)$. However, at higher concentrations, consumption was not significantly different, yielding similar larval performances. As a result, a constant residual concentration of $1500 \mu \mathrm{m}^{3} \mu \mathrm{l}^{-1}$ (or 25 cells $\mu \mathrm{l}^{-1}$ equivalent TCg diameter) of a bispecific diet is recommended for $O$. edulis larval rearing.

\section{Acknowledgement}

This work has benefited of the technical help of the team of Argenton Ifremer station, L. Lebrun, P. Le Souchu, I. Queau plus the help of a M2 student, N. Vailhe all of whom we wish to thank. This work was carried out under the frame of the European Research for SMEs, “SETTLE” project, and funded by FP7/2007-2013 under agreement no. 222043.

\section{References}

Anonymous, 2004. Report of the Working Group on Marine Shellfish Culture (WGMASC). Portland (Maine), USA, 13-15 May 2004. ICES Mariculture Committee, ICES CM 2004/F:05, Ref. G. ACME, 55pp.

Arzul, I., Gagnaire, B., Bond, C., Chollet, B., Morga, B., Ferrand, S., Robert, M., Renault, T., 2009. Effects of temperature and salinity on the survival of Bonamia ostreae, a parasite infecting flat oysters Ostrea edulis. Dis Aquat Org. 85: 67-75.

Baldwin, B. S., Newell, R. I., 1991. Omnivorous feeding by planktotrophic larvae of the eastern oyster Crassostrea virginica. Mar. Ecol. Prog. Ser. 78, 285-301. 
Baldwin, B. S., Newell, R. I., 1995. Feeding rate responses of oyster larvae (Crassostrea virginica) to seston quantity and composition. J. Exp. Mar. Biol. Ecology, 189 (1), 77-91.

Baud, J.P., Gerard, A., Naciri-Graven, Y., 1997. Comparative growth and mortality of Bonamia ostreae resistant and wild flat oyster, Ostrea edulis, in an intensive system. First year of experiment. Mar. Biol. 130, 71-79.

Bayne, B. L., 1983. Physiological ecology of marine molluscan larvae. The mollusca, 3, 299343.

Berthe, F., Le Roux, F., Adlard, R., Figueras, A., 2004. Marteiliosis in molluscs: a review. Aquat. Living Resour. 17, 433-448.

Berntsson, K.M., Jonsson, P.R., Wängberg, S.Å., Carlsson, A.S., 1997. Effects of broodstock diets on fatty acid composition, survival and growth rates in larvae of the European flat oyster, Ostrea edulis. Aquaculture 154, 139-153.

Buestel, D., Ropert, M., Prou, J., Goulletquer, P., 2009. History, status, and future of oyster culture in France. J. Shellfish Res. 28(4), 813-820.

Burke, K., Batailler, E., Miron, G., Ouellette, M., Tremblay, R., 2008. Larval quality of a nonnative bivalve species (European oyster Ostrea edulis) off the East Canadian coast. J. Shellfish Res. 27 (4), 701-710.

Castagna, M., Kraeuter, J. N., 1981. Manual for growing the hard clam Mercenaria. Special Report in Applied Marine Science and Ocean Engineering No. 249. Virginia Institute of Marine Science, Gloucester Point, VA 23062, USA. 110 pp.

Cole, H. A., 1937. Metamorphosis of the larva of Ostrea edulis. Nature, Lond, 139, 413-414.

Cole, H. A., 1938b. The fate of the larval organs in the metamorphosis of Ostrea edulis. J. Mar. Biol. Assoc. U.K. 22(02), 469-484.

Crisp, D. J., Yule, A. B., White, K. N., 1985. Feeding by oyster larvae: the functional response, energy budget and a comparison with mussel larvae. J. Mar. Biol. Assoc. U.K. 65(03), 759-783. 
Culloty, S.C., Mulcahy, M.F., 1996. Season-, age-, and sex-related variation in the prevalence of bonamiosis in flat oysters (Ostrea edulis L.) on the south coast of Ireland. Aquaculture 144, 53-63.

da Silva, P.M., Villalba, A., 2004. Comparison of light microscopic techniques for the diagnosis of the infection of the European flat oyster Ostrea edulis by the protozoan Bonamia ostreae. J. Invertebr. Pathol. 85, 97-104.

da Silva, P.M., Fuentes, J., Villalba, A., 2005. Growth, mortality and disease susceptibility of oyster Ostrea edulis families obtained from brood stocks of different geographical origins, through on-growing in the Ria de Arousa (Galicia, NW Spain). Mar. Biol. 147, 965-977.

Davis, H. C., Calabrese, A., 1964. Combined effects of temperature and salinity on development of eggs and growth of larvae of M. mercenaria and C. virginica. Fish. Bull. 63(3), 643-655.

Davis, H. C., Calabrese, A., 1969. Survival and growth of larvae of the European oyster (Ostrea edulis L.) at different temperatures. Bio. Bull. 136 (2), 193-199.

Davis, H. C., Hidu, H., 1969. Effects of pesticides on embryonic development of clams and oysters and on survival and growth of the larvae. Fish. Bull. 67(2), 393-404.

Elston, R., Häse, C., Hasegawa, H., Humphrey, K., Polyak, I., 2008. Re-emergence of Vibriosis in shellfish hatcheries and nurseries. J. Shellfish. Res., 27 (4), 1005-1005.

Fabioux, C., Huvet, A., Le Souchu, P., Le Pennec, M., Pouvreau, S., 2005. Temperature and photoperiod drive Crassostrea gigas reproductive internal clock. Aquaculture 250, 458-470.

Flannery, G., Lynch, S.A., Carlsson, J., Cross, T.F., Culloty, S.C. 2014. Assessment of the impact of a pathogen, Bonamia ostreae, on Ostrea edulis oyster stocks with different histories of exposure to the parasite in Ireland. Aquaculture 432, 243-251.

Ford, S.E., Figueras, A.J., Haskin, H.H., 1990. Influence of selective breeding, geographic origin, and disease on gametogenesis and sex-ratios of oysters, Crassostrea virginica, exposed to the parasite Haplosporidium-nelsoni (msx). Aquaculture 88, 285-301. 
Gallager, S. M., 1988. Visual observations of particle manipulation during feeding in larvae of a bivalve mollusc. Bulletin of Marine Science. 43(3), 344-365.

González-Araya, R., Quéau, I., Quéré, C., Moal, J., Robert, R., 2011. A physiological and biochemical approach to selecting the ideal diet for Ostrea edulis (L.) broodstock conditioning (Part A). Aquaculture Research 42, 710-726.

González-Araya, R., Lebrun, L., Quéré, C., Robert, R., 2012a. The selection of the ideal diet for Ostrea edulis (L.) broodstock conditioning (part B). Aquaculture 362-363, $55-66$.

Gonzalez-Araya, R., Mingant, C., Petton, B., Robert, R., 2012b. Influence of diet assemblage on Ostrea edulis broodstock conditioning and subsequent larval development. Aquaculture $364,272-280$.

González-Araya, R., Quillien V., Robert R., 2013. The effect of eight single microalgal diets on sex-ratio and gonad development throughout European flat oyster (Ostrea edulis L.) conditioning. Aquaculture 400-401, 1-5.

Grizel, H., Héral, M., 1991. Introduction into France of the Japanese oyster (Crassostrea gigas). Journal du Conseil-CIEM 47, 399-403.

Harrang, E., Heurtebise, S., Faury, N., Robert, M., Arzul, I., Lapègue, S., 2015. Can survival of European oysters following experimental infection with Bonamia ostreae be predicted using QTLs. Aquaculture 448, 521-530.

Harry, H. W., 1985. Synopsis of the supraspecific classification of living oysters (Bivalvia: Gryphaeidae and Ostreidae). The Veliger 28(2), 121-158.

Haws, M. C., DiMichele, L., Hand, S. C., 1993. Biochemical changes and mortality during metamorphosis of the Eastern oyster, Crassostrea virginica, and the Pacific oyster, Crassostrea gigas. Mol. Mar. Biol. Biotechnol. 2(4), 207-217.

Helm, M.M., Millican P.F., 1977. Experiments in the hatchery of Pacific oyster (Crassostrea gigas Thunberg). Aquaculture 11, 1-12. 
Helm, M. M., Pellizzato, M., 1990. Riproduzione ed allevamento in schiuditoio della specie Tapes philippinarum, 117-140. Tapes philippinarum: Biologia e Sperimentazione. Ente Svillupo Agricolo Veneto, Venice, Italy, pp. 1-299.

Hidu, H., Lavoie, R. E., 1991. The European oyster, Ostrea edulis L. Maine and Eastern Canada. In W. Menzel (ed.), Estuarine and Marine Bivalve Mollusk Culture, 36-46.

Holland, D. L., Spencer, B. E., 1973. Biochemical changes in fed and starved oysters, Ostrea edulis L. during larval development, metamorphosis and early spat growth. J. Mar. Biol. Assoc. U.K. 53(02), 287-298.

Jeffries, V.E., 1983. Three Vibrio strains pathogenic to larvae of Crassostrea gigas and Ostrea edulis. Aquaculture 29, 201-226.

Labarta, U., Fernández-Reiriz, M. J., Pérez-Camacho, A., 1999. Larvae of Ostrea edulis (L.) during starvation: growth, energy and biochemical substrates. Hydrobiologia 405, 125-131.

Laing, I., Walker, P., Areal, F., 2005. A feasibility study of native oyster (Ostrea edulis) stock regeneration in the United Kingdom. CARD project FC1016, Native oyster Stock Regeneration-A review of Biological, Technical and Economic Feasibility, 95pp.

Lallias, D., Arzul, I., Heurtebise, S., Ferrand, S., Chollet B., Robert M., Beaumont, A.R., Boudry P., Morga B., Lapègue S., 2008. Bonamia ostreae-induced mortalities in one-year old European flat oysters Ostrea edulis: experimental infection by cohabitation challenge. Aquat. Living Resour. 21, 423-439.

Lallias, D., Gomez-Raya, L., Haley, C.S., Arzul, I., Heurtebise, S., Beaumont, A.R., Boudry, P., Lapègue, S., 2009. Combining two-stage testing and interval mapping strategies to detect QTL for resistance to bonamiosis in the European flat oyster Ostrea edulis. Mar. Biotechnol. $11,570-584$.

Lallias, D., Boudry, P., Lapegue, S., King, J.W., Beaumont, A.R., 2010. Strategies for the retention of high genetic variability in European flat oyster (Ostrea edulis) restoration programmes. Conserv. Genet. 11, 1899-1910.

Le Bec, C., Mazurie, J., Cochennec, N., le Coguic, Y., 1991. Influence of Crassostrea gigas mixed with Ostrea edulis on the incidence of Bonamia disease. Aquaculture 93, 263-27 1. 
Lynch, A.S., Flannery, G., Hugh-Jones, T., Hugh Jones, D., Culloty, S., 2014. Thirty-year history of Irish (Rossmore) Ostrea edulis selectively bred for disease resistance to Bonamia ostreae. Dis Aquat Org. 110, 113-121.

Magnesen, T., Bergh, Ø., Christophersen, G., 2006. Yields of great scallop, Pecten maximus, larvae in a commercial flow-through rearing system in Norway. Aquacult. Inter. 14(4), 377394.

Martín-Gómez, L., Villalba, A., Carballal, M.J., Abollo, E., 2012. Cloning and characterization of neoplasia-related genes in flat oyster Ostrea edulis. Infection, Genetics and Evolution 23, 138-149.

Montes, J., Villalba, A., Lopez, M.C., Carballal, M.J., Mourelle, S.G., 1991. Bonamiasis in native flat oysters (Ostrea edulis L.) from two intertidal beds of the Ortigueira Estuary (Galicia, N.W. Spain) with different histories of oyster culture. Aquaculture 93, 213-224.

Montes, J., Ferro-Soto, B., Conchas, R.F., Guerra, A., 2003. Determining culture strategies in populations of the European flat oyster, Ostrea edulis, affected by bonamiosis. Aquaculture $220,175-182$.

Morga, B., Arzul, I., Faury, N., Renault, T., 2010. Identification of genes from flat oyster Ostrea edulis as suitable housekeeping genes for quantitative real time PCR. Fish Shellfish Immunol. 29, 937-945.

Morga, B., Renault, T., Arzul, I., 2012. New insights in flat oyster Ostrea edulis resistance against the parasite Bonamia ostreae. Fish Shellfish Immunology 32, 958-968.

Naciri-Graven, Y., Martin, A.G., Baud, J.P, Renault T., Gérard A., 1998. Selecting the flat oyster Ostrea edulis (L.) for survival when infected with the parasite Bonamia ostreae. J. Exp. Mar. Biol. Ecol. 224:91-107.

Pascual, M., Martin, A.G., Zampatti, E., Coatanea, D., Deffosez, J., Robert, R., 1991. Testing of the Argentina oyster, Ostrea puelchana, in several French oyster farming sites. ICES, $\mathrm{CM} / \mathrm{K}: 30: 18 \mathrm{p}$. 
Pernet, F., Barret, J., Le Gall, P., Corporeau, C., Degremont, L., Lagarde, F., Pepin, J.F., Keck, N., 2012. Mass mortalities of Pacific oysters Crassostrea gigas reflect infectious diseases and vary with farming practices in the Mediterranean Thau lagoon, France. Aquacult. Environ. Interact. 2: 215-237.

Prado, S., Romalde, J. L., Montes, J., Barja, J. L., 2005. Pathogenic bacteria isolated from disease outbreaks in shellfish hatcheries. First description of Vibrio neptunius as an oyster pathogen. Dis. Aquat. Org. 67(3), 209-215.

Prado-Alvarez, M., Lynch, S.A., Kane, A., Darmody, G., Pardo, B.G., Martínez, P., Cotterill, J., Wontner-Smith, T., Culloty, S.C., 2015. Oral immunostimulation of the oyster Ostrea edulis: Impacts on the parasite Bonamia ostreae. Fish \& Shellfish Immunology 45, 43-51.

Renault, T. 2011. A review of mortality outbreaks in the Pacific oyster, Crassostrea gigas, reported since 2008 in various European Union Member States and the related implementation of Council Directive 2008/88/EC. Bulletin OIE 4: 51-52.

Rico-Villa, B., Woerther, P., Mingant, C., Lepiver, D., Pouvreau, S., Hamon, M., Robert, R., 2008. A flow-through rearing system for ecophysiological studies of Pacific oyster Crassostrea gigas larvae. Aquaculture 282(1), 54-60.

Rico-Villa, B., Pouvreau, S., Robert, R. 2009. Influence of food density and temperature on ingestion, growth and settlement of Pacific oyster larvae, Crassostrea gigas. Aquaculture 287(3), 395-401.

Rico-Villa, B., Bernard, I., Robert, R., Pouvreau S., 2010. A Dynamic Energy Budget (DEB) growth model for Pacific oyster larvae, Crassostrea gigas. Aquaculture, 305, 84-94.

Robert, R., His, E., Dinet, A., 1988. Combined effects of temperature and salinity on fed and starved larvae of the European flat oyster Ostrea edulis. Mar. Biol. 97, 95-100.

Robert, R., Borel, M., Pichot, Y., Trut, G., 1991. Growth and mortality of the European oyster Ostrea edulis in the bay of Arcachon (France). Aquat. Living Resour. 4, 265-274.

Robert, R., Luis-Sanchez, J., Pérez-Parallé, L., Ponis, E., Kamermans, P., O’Mahoney, M., 2013. A glimpse of the mollusc industry in Europe. Aquaculture Europe, 38 (1), March 2013, 5-11. 
Sawusdee, A., Jensen, A.C., Collins, K.J., Hauton, C., 2015. Improvements in the physiological performance of European flat oysters Ostrea edulis (Linnaeus, 1758) cultured on elevated reef structures: Implications for oyster restoration. Aquaculture 444, 41-48.

Shpigel, M., 1989. Gametogenesis of the European flat oyster (Ostrea edulis) and Pacific oyster (Crassostrea gigas) in warm water in Israel. Aquaculture 80(3), 343-349.

Strathmann, R. R., 1978. The evolution and loss of feeding larval stages of marine invertebrates. Evolution 32 (4), 894-906.

Strathmann, R. R., Leise, E., 1979. On feeding mechanisms and clearance rates of molluscan veligers. Bio. Bull. 157(3), 524-535.

Utting, S. D., Spencer, B. E., 1991. The hatchery culture of bivalve mollusc larvae and juveniles. Ministry of Agriculture, Fisheries and Food, Laboratory Leaflet No 68.

van Banning, P., 1990. The life cycle of the oyster pathogen Bonamia ostreae with a presumptive phase in the ovarian tissue of the European flat oyster, Ostrea edulis. Aquaculture 84,189-192.

Walne, P. R., 1965. Observations on the influence of food supply and temperature on the feeding and growth of the larvae of Ostrea edulis L. Fishery Invest., London, Serie 2, 24 (1).

Walne, P. R., 1966. Experiments in the large-scale culture of the larvae of Ostrea edulis L. Fishery Invest., London, Serie 2, 25 (4).

Walne, P. R., 1979. Culture of bivalve molluscs: 50 years' experience at Conwy (No. Ed. 2). Fishing News Books Ltd.

Ward, R.D., English, L.J., McGolddrick, D.J., Maguire, G.G., Nell, J.A., Thompson P.A., 2000. Genetic improvement of the Pacific oyster Crassostrea gigas (Thunberg) in Australia. Aquatic Research 31, 35-44. 


\section{Legend of tables}

Table 1. Effects of four seawater temperatures on mean larval survival, competence and settlement rates of $O$. edulis $( \pm \mathrm{SD}$ ) during pelagic and benthic phase (trial 1$) .{ }^{\circ} \mathrm{d}$ : ${ }^{\circ}$ days or degree-days; D: day.

Table 2. Effects of two seawater temperatures on mean $( \pm$ SD) larval survival and growth from day 9 and settlement from day 18 in $O$. edulis (trial 2). ${ }^{\circ}$ : ${ }^{\circ}$ days or degree-days.

Table 3. Effects of food concentration on larval survival, competence (day 6) and settlement (day 13) of $O$. edulis. $70 \mu \mathrm{m} 3 \mu \mathrm{l}^{-1}$ correspond to unfed larvae which only received continuously $1 \mu \mathrm{m}$-filtered UV treated seawater.

\section{Legend of figures}

Figure 1. Experimental design used to allow the continuous thermoregulation of the four temperatures in flow through from 15 to $30^{\circ} \mathrm{C}$.

Figure 2. Effects of four seawater temperatures on microalgae consumption in $O$. edulis larvae (trial 1) during larval and benthic phases.

Figure 3. Effects of four seawater temperatures on O. edulis larval growth (trial 1).

Figure 4. Effects of phytoplankton concentration on microalgae consumption in O. edulis larvae.

Figure 5. Effects of phytoplankton concentration on O. edulis larval growth. 
Table 1.

\begin{tabular}{|c|c|c|c|c|c|}
\hline & \multicolumn{3}{|c|}{ Larval survival (\%) } & \multirow{2}{*}{$\begin{array}{c}\text { Competence } \\
(\%)\end{array}$} & \multirow{2}{*}{ 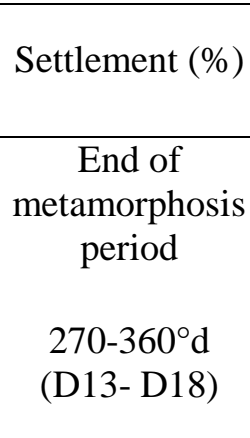 } \\
\hline $\begin{array}{c}\text { Temperature } \\
\left({ }^{\circ} \mathrm{C}\right)\end{array}$ & $\begin{array}{l}\text { End of larval } \\
\text { rearing period } \\
175-195^{\circ} \mathrm{d} \\
\text { (D6-D13) }\end{array}$ & $\begin{array}{c}\text { Mid } \\
\text { metamorphosis } \\
\text { period } \\
240-270^{\circ} \mathrm{d} \\
\text { (D9-D16) }\end{array}$ & $\begin{array}{c}\text { End of } \\
\text { metamorphosis } \\
\text { period } \\
\\
270-360^{\circ} \mathrm{d} \\
(\mathrm{D} 13-\mathrm{D} 18)\end{array}$ & & \\
\hline 15 & $79.0(16.7)$ & $42.9(44.6)$ & $0.0(0.0)$ & $11.7(3.2)$ & $0.0(0.0)$ \\
\hline 20 & $92.7(3.3)$ & $0.0(0.0)$ & ---- & $51.7(1.5)$ & $26.7(1.1)$ \\
\hline 25 & $99.4(0.2)$ & $10.8(6.0)$ & $0.3(0.4)$ & $89.0(2.0)$ & $78.3(4.7)$ \\
\hline 30 & $97.2(1.0)$ & $7.8(3.3)$ & $0.5(0.3)$ & $96.0(1.0)$ & $91.7(1.1)$ \\
\hline
\end{tabular}


Table 2

\begin{tabular}{|c|c|c|c|c|}
\hline $\begin{array}{c}\text { Temperature } \\
\left({ }^{\circ} \mathrm{C}\right)\end{array}$ & $\begin{array}{c}\text { Period of larval } \\
\text { rearing (days) } \\
225^{\circ} \mathrm{d}\end{array}$ & $\begin{array}{c}\text { Survival } \\
(\%)\end{array}$ & $\begin{array}{c}\text { Growth } \\
\left(\mu \mathrm{m} \mathrm{d}^{-1}\right)\end{array}$ & $\begin{array}{c}\text { Settlement } \\
(\%)\end{array}$ \\
\hline 20 & 11 & $42.2(12.5)$ & $9.1(4.8)$ & $25.0(3.6)$ \\
\hline 25 & 9 & $52.7(9.3)$ & $15.5(6.8)$ & $\begin{array}{c}\text { No data } \\
\text { (overflow) }\end{array}$ \\
\hline
\end{tabular}


Table 3

\begin{tabular}{|c|c|c|c|c|c|}
\hline & \multicolumn{3}{|c|}{ Larval survival (\%) } & $\begin{array}{c}\text { Competence } \\
(\%)\end{array}$ & $\begin{array}{c}\text { Settlement } \\
(\%)\end{array}$ \\
\hline $\begin{array}{c}\text { Phytoplankton } \\
\text { density } \\
\left(\mu \mathrm{m}^{3} \mu 1^{-1)}\right.\end{array}$ & Day 6 & Day 10 & Day 13 & Day 6 & Day 13 \\
\hline 70 & $89.1(5.3)$ & $44.4(8.9)$ & 0 & 0 & 0 \\
\hline 500 & $96.8(1.6)$ & $69.4(16.4)$ & $0.2(0.3)$ & $16.8(26.7)$ & $22.9(20.3)$ \\
\hline 1500 & $98.0(1.4)$ & $19.3(9.3)$ & $0.1(0.2)$ & $16.5(5.7)$ & $68.1(3.6)$ \\
\hline 2500 & $95.7(1.8)$ & $19.6(4.1)$ & 0 & $10.2(4.8)$ & $54.2(7.8)$ \\
\hline 3500 & $96.8(1.6)$ & $28.5(8.6)$ & $0.3(0.3)$ & $8.2(2.9)$ & $52.1(4.6)$ \\
\hline
\end{tabular}




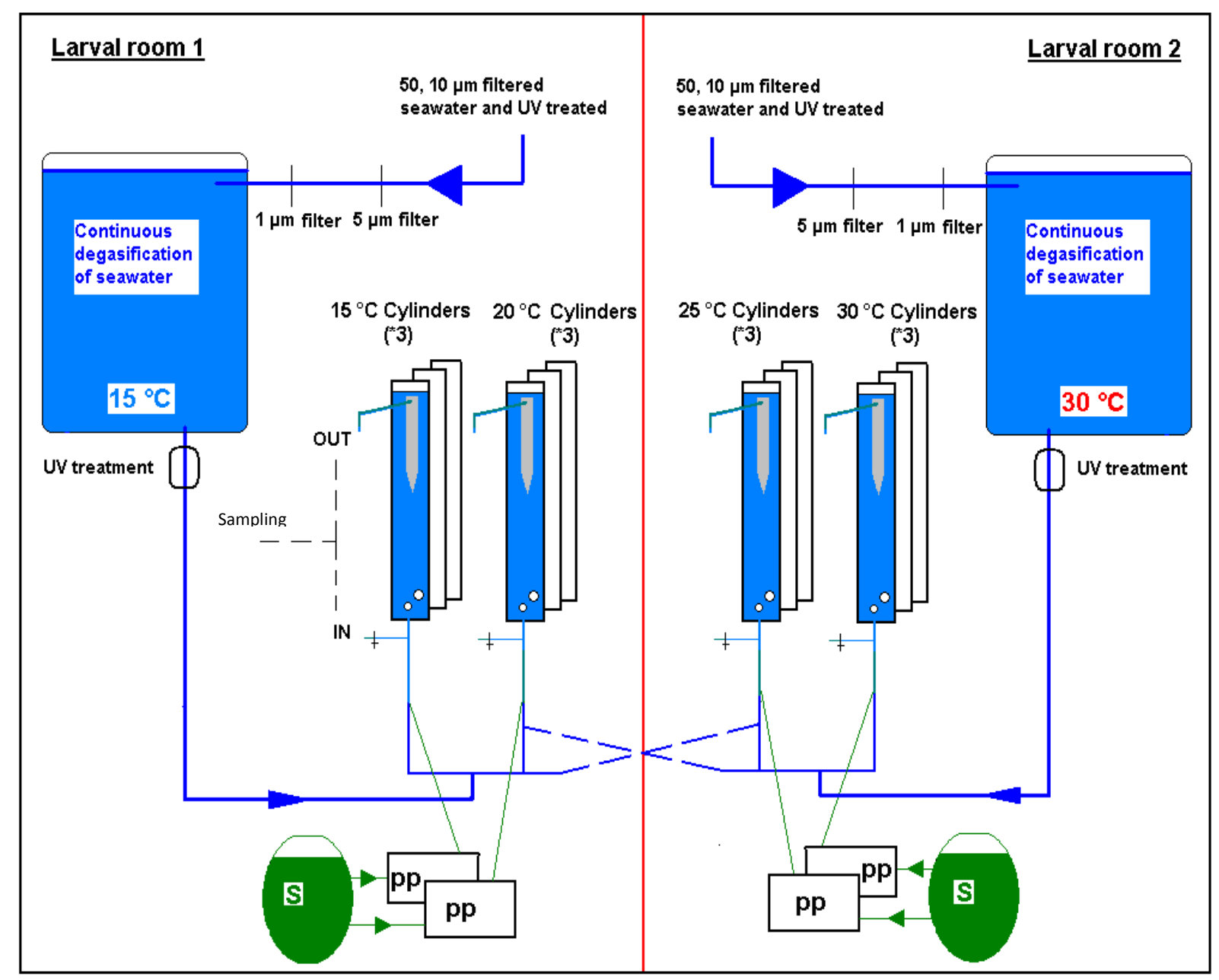

Figure 1 


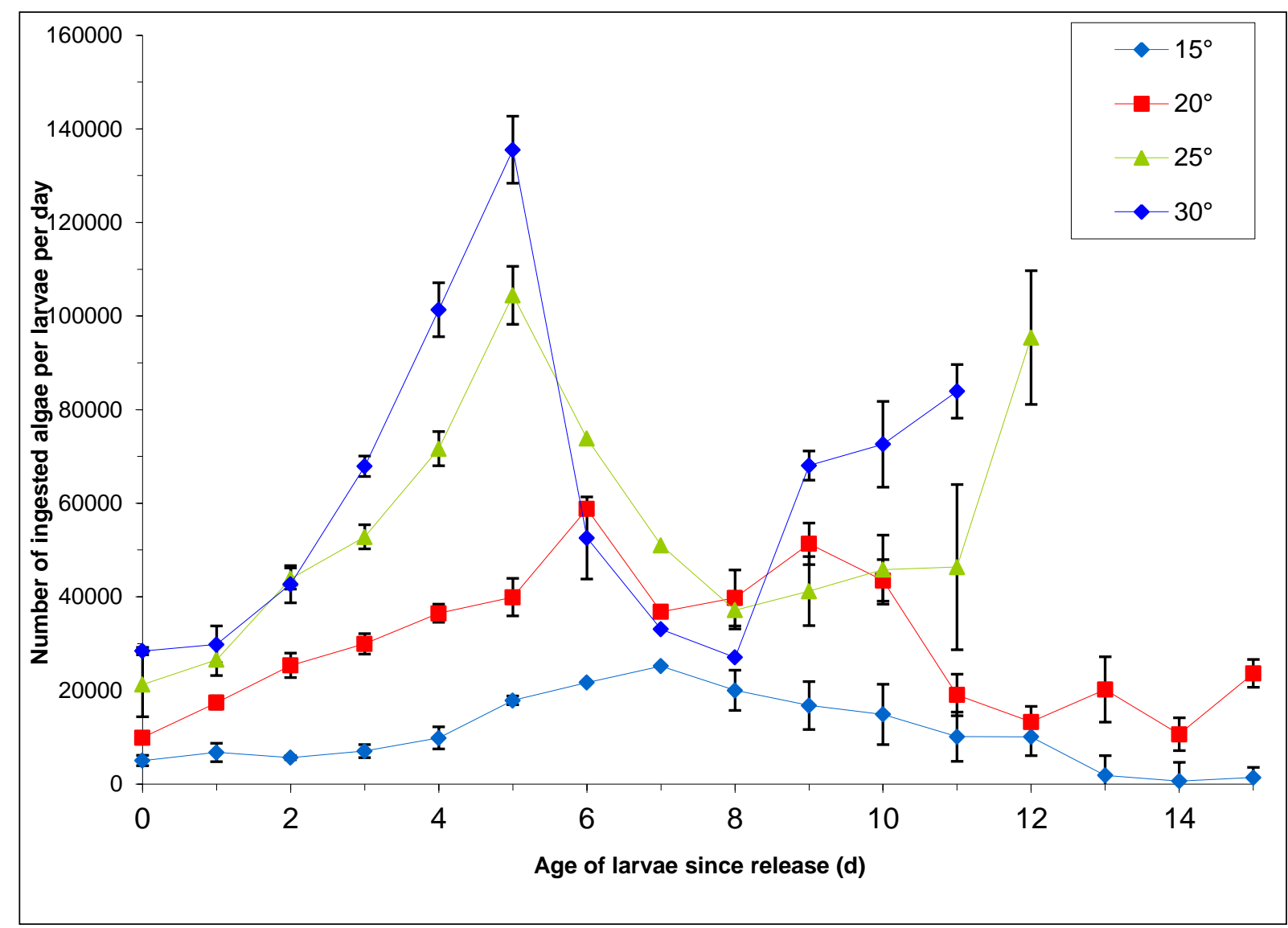

Figure 2 


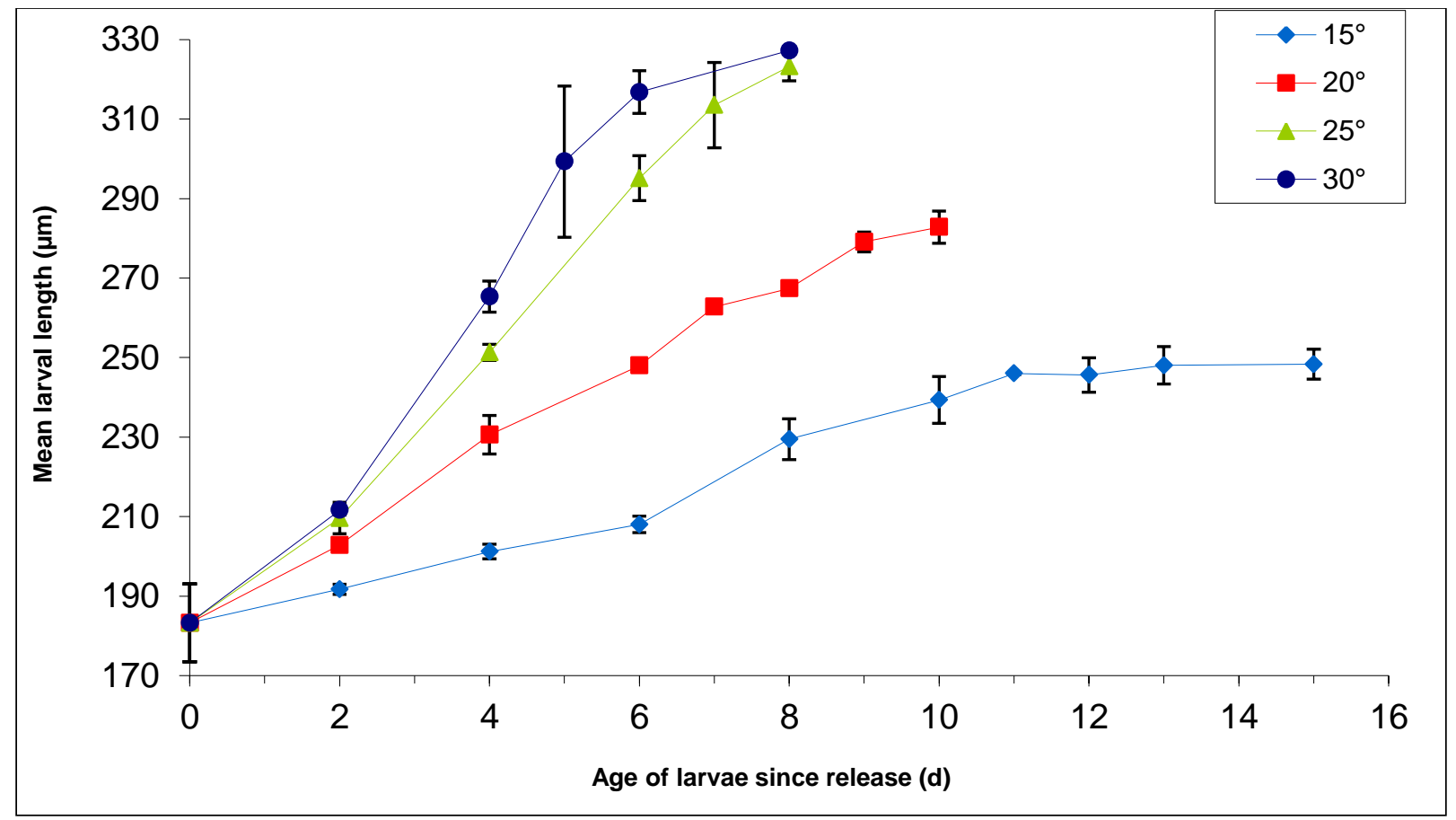

Figure 3. 


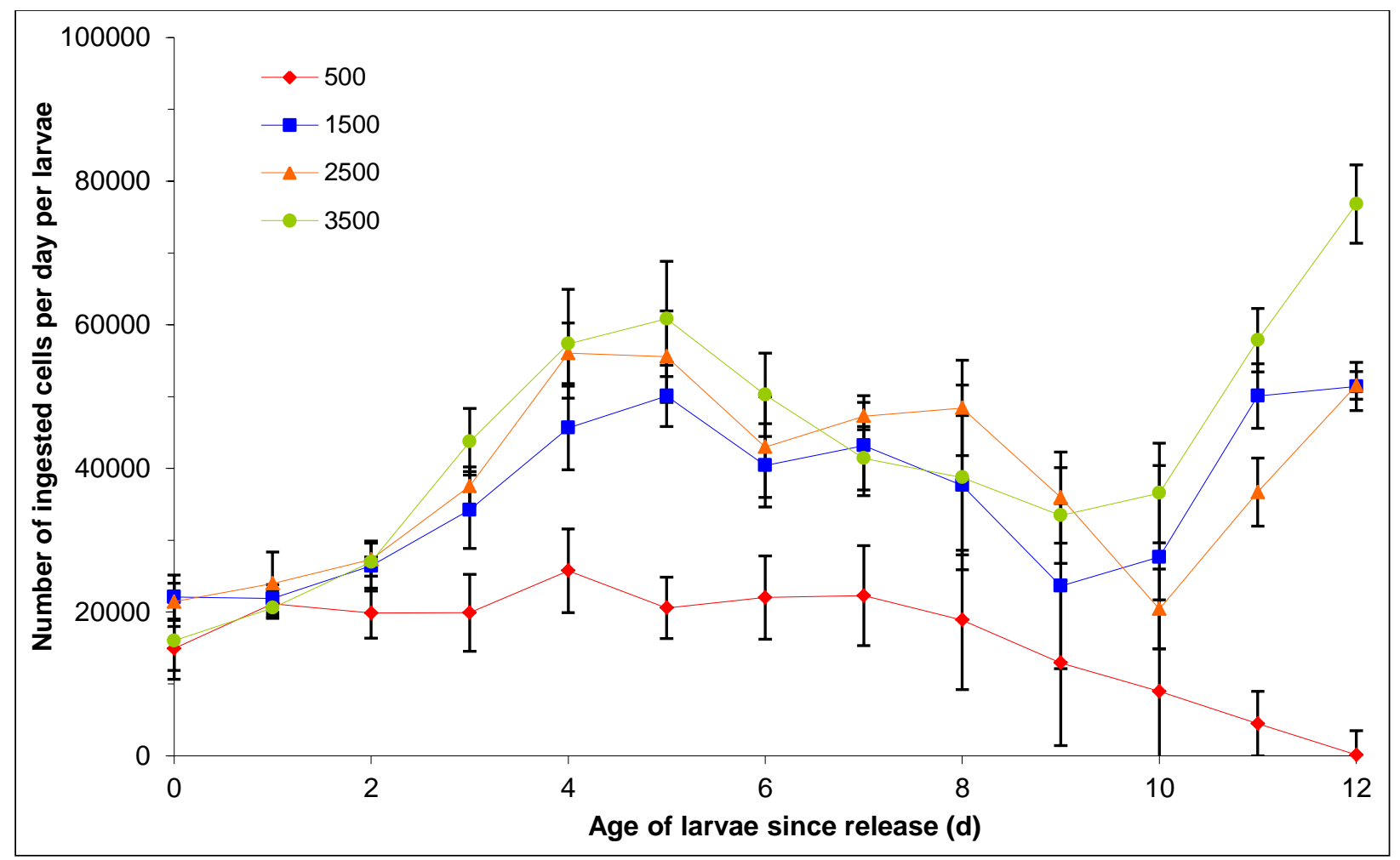

Figure 4. 


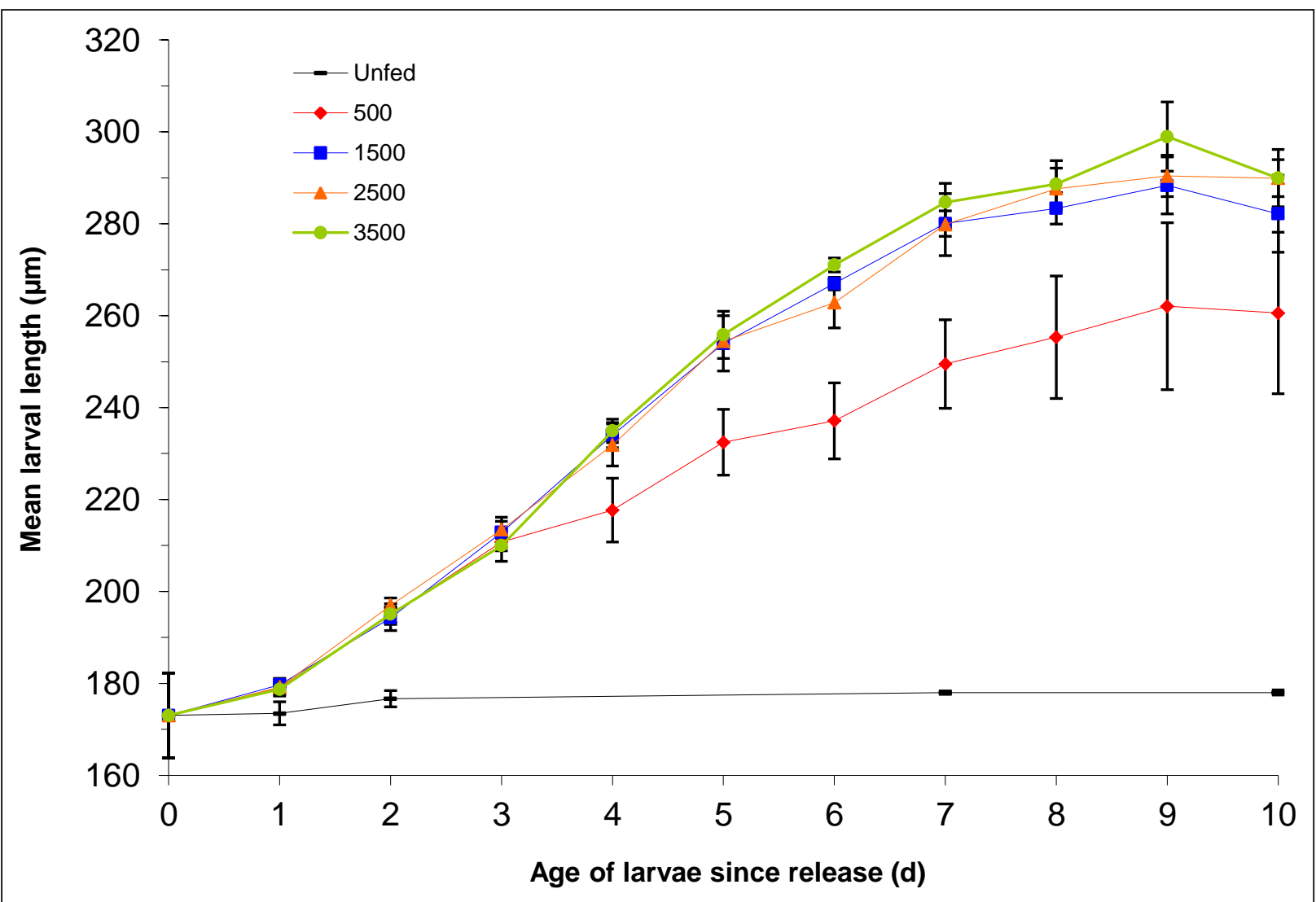

Figure 5. 